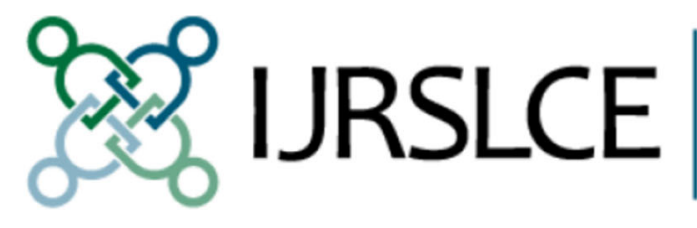

International Journal

for Research on

Service-Learning \&

Community Engagement

\title{
Student Development and Service- Learning: A Three-Phased Model for Course Design
}

\section{Carrie Williams Howe}

Kimberly Coleman, Kelly, Hamshaw, Katherine Westdijk

This article was originally published at:

https://journals.sfu.ca/iarslce/index.php/journal/article/view/86/34

Recommended Citation

Williams Howe, C. W., Coleman, K., Hamshaw, K., \& Westdijk, K. (2014). Student development and service-learning: A three-phased model for course design. International Journal of Research on Service-Learning and Community Engagement, 2(1). 44-62. 


\title{
Student Development and Service-Learning: A Three-Phased Model for Course Design
}

\author{
Carrie Williams Howe \\ Vermont Campus Compact \\ Kimberly Coleman \\ Virginia Polytechnic Institute and State University \\ Kelly Hamshaw \\ Katherine Westdijk \\ University of Vermont
}

\begin{abstract}
Many key resources in service-learning literature offer tools and advice to faculty members for designing effective service-learning courses; these materials typically focus on integrating service-learning effectively into a syllabus, fostering reciprocal partnerships, and using reflection to analyze experience. In addition, a number of research studies have explored the impact of participation in service-learning on student development outcomes. However, very few resources "flip" this equation-that is, there is less information in the literature on how student development theory can inform the effective design of service-learning courses and curricula. This article utilizes an extensive review of student/adult development and learning theory to propose a three-phased model for service-learning course design. Informed by the authors' experiences working with faculty members and departments, the article provides examples illustrating the potential impact of this approach for individual courses or sequential curricula.
\end{abstract}

Keywords: service-learning; student-development outcomes; course design

Service-learning courses combine academic learning goals with community-based projects such that each informs the other, with the goals of both meeting community-identified needs and enhancing student learning and development. As a pedagogical approach, service-learning has been touted as a "high impact educational practice" by the American Association of Colleges and Universities (Kuh, 2008) for its ability to impact student success and satisfaction in college, and has emerged as a common practice on most college campuses. Discipline-based service-learning courses are increasingly offered at U.S. colleges and universities (Campus Compact, 2013), making it important to explore the factors that contribute to successful service-learning, the impacts service-learning can have on students and communities, and how to best support and evaluate the practice.

Service-learning scholars have identified a core set of priorities for effective course design, with reflection, academic rigor, and reciprocal partnerships topping most lists (Enos \& Troppe, 1996; Eyler \& Giles, 1999; Howard, 1993; Mintz \& Hesser, 1996). Service-learning course/curriculum guides turn these best practices into concrete suggestions for course design (Gordon, 2000; Heffernan, 2001; Howard, 2001; Seifer \& Connors, 2007), with new perspectives being added regularly (such as Butin's 2003 conceptual reframing of service-learning practice and theory). Scholars have also documented the impacts of service-learning on student development, including improvements in cognitive skills, career identification, interpersonal skills, and more (Eyler \& Giles, 1999; Eyler, Giles, Stenson, \& Gray, 2001; Jameson, Clayton, \& Bringle, 2008). Yet, important questions remain for those who implement the practice: What are my students ready for? How big should the project be? How much independence can 
I give my students? Why aren't my students producing what I think they are capable of? While general principles of good practice are useful in designing courses, the same design models cannot, and should not, apply to all courses; students in their first year of college have different needs and skills from seniors, and those who have never been exposed to service-learning are going to perform differently from those for whom it is a regular occurrence. While there are undoubtedly campuses and individual faculty members who are effectively using student development to inform course design, there is limited empirical research and are fewer readily available models to guide these discussions, especially at the most practical and direct levels. This gap has led, in our experience, to a frequent mismatch between student readiness and faculty or community expectations; without this literature there is a missed opportunity to help students reach higher levels of skill and capacity by creating progressive, strategically designed, curricular service-learning programs.

We have drawn on existing student development theory and our own experience to create, use, and test the Three-Phased Model of Service-Learning Course Design. We found that this model helps faculty to access developmental theories in a way that can be applied practically and meaningfully, and also helps them to address challenges and concerns related to this pedagogical approach. As the examples illustrate, we have used this model successfully with individual faculty members as well as at the departmental and institutional levels.

\section{Literature Review}

Because there is a wide range of resources available on service-learning pedagogy, it is important to understand how our model relates to and builds upon current literature while also offering a new perspective to the field. In addition to a review of general service-learning course design literature and resources that outline the impacts of service-learning on student development (see above), we conducted a comprehensive literature search for articles that used student development theory to inform servicelearning course design. This search revealed a small but valuable collection of theoretical and researchbased articles (Berle, 2006; Bradley, 2003; McEwan, 1996; Morton, 1996; Steinke, Fitch, Johnson, \& Waldstein, 2002; Terry \& Bohnenberger, 2004; Warter \& Grossman, 2002). Some of these resources offered promising contributions to developmental discussions but did not explicitly articulate implications for course design. For example, Morton (1996) articulated important questions that faculty must consider when designing service-learning; some of these questions could, by extension, be tied to student development issues (such as the centrality of service to the overall course and the amount of service included). Likewise, Steinke et al. (2002) sought further knowledge about which program design characteristics would most heavily impact outcomes in cognitive learning, intellectual development, spiritual and ethical development, civic engagement, and community benefit, but they did not explicitly address how this information could translate directly to course design. A theoretical piece by Warter and Grosman (2002) connected the concept of "developmental contextualism" to service-learning program design. Warter and Grossman argued that individual characteristics could impact outcomes of servicelearning and that those characteristics should be recognized in designing service-learning (pp. 85-86). In discussing program design, they stressed the importance of developmental fit; however, the practical implications of this concept for course design were not thoroughly explored. Other articles touched on the concept of progressive course design but did not draw developmental theory into the practical considerations they presented. For example, Berle (2006) outlined the strategy of "incremental integration" of service-learning into a horticulture major, focusing heavily on the gradual introduction and building of skills and knowledge among students but not making direct connections to developmental theory.

Three resources came closest to using developmental theory to inform course design, and we suggest a review of these articles for those wishing to dig deeper into these theoretical concepts. First, Terry and Bohnenberger (2004) presented a model for service-learning integration in K-12 curriculum that built on developmental principles. This model began with engaging students in community service, moved through community exploration, and culminated in community action. Building primarily upon Piaget's 
46 | International Journal of Research on Service-Learning and Community Engagement

cognitive learning theory $(1952 ; 1972)$, this model focused on how students perceive or understand issues - from concrete, personalized understanding to an ability to be highly involved with abstract societal issues (Terry \& Bohenenberger, 2004, pp. 22-23). They articulated a need to "look beyond isolated service experiences and implement a sequential approach to service learning" (p. 28). Types of activities, impact on partners, and student skills to be developed were presented in sequence for each level, and a model was presented that tied these elements together (p. 21). Our model has similar goals but moves into developmental theory at the college level, spells out more specific course design options, and expands beyond cognitive development to other developmental considerations (e.g., moral, psychosocial, etc.).

McEwen (1996) provided a comprehensive overview of developmental theories closely related to service-learning and suggested considerations for service-learning program design within each developmental category. McEwan's primary goal was not to create a detailed tool for course design; consequently, some suggestions are more concrete than others. For example, citing the "challenge and support" theory (Sanford, 1962), McEwan reminded practitioners of the critical need for the "complementarity of the challenge and support and the appropriateness of the balance for the individual" (p. 56). She pointed to the necessity of careful consideration of developmental goals and outcomes within service-learning programs: "[I]n designing service-learning experiences, educators should draw on relevant theoretical perspectives about the development of college students from the cognitive, psychosocial, identity, and career development domains" (p. 87). Our model translates McEwan's general themes into concrete course design options and choices that are easily translatable for faculty who have limited experience with student development theory.

Bradley (2003) asked two key questions in an article connecting student development to servicelearning: Are there reasons to believe that service-learning programs will have positive impacts on K-16 students; and if so, what do developmental or learning theories suggest about the design and evaluation of such programs? It is the latter question that is of most interest to our model. Because Bradley included K-16 education, his article addressed development that happens both before and during college. He explored psychosocial, cognitive, and learning style theories, using comprehensive tables for each that outlined key developmental challenges and "service-learning support mechanisms" that can help to address these challenges. Bradley focused on how courses can be designed to promote developmental outcomes among students, and his article is another useful companion to our model, with valuable suggestions presented within each table. Building upon this work, our model combines diverse developmental charts into one phased model. We also focus on the use of developmental theory to improve service-learning experiences for other stakeholders, including faculty and community partners.

\section{Scaffolding: An Overarching Concept}

An important concept that informs the overall design of our model is the notion of "scaffolding," a term coined by Bruner (1956) and closely related to Vygotsky's $(1962 ; 1978)$ work on the Zone of Proximal Development (ZPD). Vygotsky's contribution to the field of cognitive development describes "how the social environment around us influences our intellectual development” (Merriam et al., 2007, p. 360). He described the ZPD as:

The distance between the actual developmental level, as determined by independent problemsolving, and the level of potential development, as determined through problem solving under adult guidance or in collaboration with more capable peers. (Vygotsky, 1978, p. 86)

Scaffolding in a developmental/educational sense entails providing temporary support as a student learns a new concept or task. The role of the instructor is to provide that support as the student climbs toward the next level of understanding or capacity, and to gradually remove (or shift) that support as the student becomes more skilled and confident (as the metaphoric building stands more securely on its own). By scaffolding, our model supports students in moving up to the next closest level, one step at a time, 
rather than expecting them to make huge strides without support. Indeed, this concept underlies the creation of the Three-Phased Model.

\section{Theory to Practice: Building a Developmental Model}

The Three-Phased Model for Service-Learning Course Design uses available developmental theory to inform the choices that faculty members make in designing service-learning courses or sequenced curricula (see Table 1). In this section, we outline the theoretical perspectives most useful for each of the five course considerations included in the model. We then outline how service-learning courses could be effectively designed in light of these theoretical perspectives and provide relevant examples from our practice in order to illustrate the bridge between theory and practice (application). Following detailed exploration of these considerations, we offer a model that fuses them into a cohesive three-phased approach.

\section{Considerations 1 and 2: Instructor Role and Level of Student Responsibility}

\section{Theoretical Background}

Students at different developmental levels and with differing ranges of prior experience in servicelearning will need different types of support from their instructors. Likewise, a learner's ability to manage his or her learning is a skill that is developed over time and not necessarily present early in an academic career. Our suggestions for how the role of a faculty member might differ in the phases of our model (and in turn how student responsibility might evolve) are most heavily influenced by epistemological developmental theory and self-directed learning theory. Rooted in and influenced by the work of Piaget on child and adolescent development $(1952,1972)$, cognitive development theory explores what happens in the brain of an individual that helps him or her to move toward complex thoughts about the world. Epistemological development theories, on the other hand, ask how individuals develop the capacity to think about their own thinking (otherwise known as metacognition) and to make sense of the knowledge that comes from their own as well as others' perspectives; they ask, "How do we know?" and "What can be known?". Common among these theories is an evolution from a dualistic mode of understanding the world (right/wrong) that relies on the knowledge of authority figures, to an understanding that prioritizes personal experience (subjective/relative), to a more complex understanding that balances subjective, experiential knowledge with expert opinion in order to come to decisions about the world (Belenky, Clinchy, Goldberger, \& Tarule, 1997; Kegan, 1998; King \& Kitchener, 1994; Magolda, Creamer, \& Maszaros, 2010; Perry, 1998). Much of this research has shown that traditionalaged students enter college either in the dualistic mode or early in the subjective/relative mode (King \& Kitchener, 1994; Perry, 1998). The ability to think about one's own thinking, to understand the process through which one comes to a decision, and to integrate one's own experience with what one has learned from others is a significant change that does not always fully develop within the college years (King \& Kitchener, 1994). Transformational learning theory (Mezirow, 1991) posits that the ability to move toward more complex thinking and self-direction is often sparked by moments of discomfort combined with the ability to reflectively process those experiences. 
Table 1. Course Considerations and Developmental Perspectives

\begin{tabular}{|c|c|c|c|c|c|}
\hline $\begin{array}{c}\text { Course } \\
\text { Considerations }\end{array}$ & $\begin{array}{c}\text { Developmental } \\
\text { Perspectives }\end{array}$ & \multicolumn{4}{|c|}{ Suggestions for Course Design } \\
\hline Instructor Role & $\begin{array}{l}\text { Epistemological } \\
\text { Development }^{\mathrm{a}} \\
\text { Self-Directed } \\
\text { Learning }^{\mathrm{b}}\end{array}$ & $\begin{array}{l}\text { Authority/ } \\
\text { Coordinator }\end{array}$ & $\begin{array}{l}\text { Motivator/ } \\
\text { Guide }\end{array}$ & Facilitator/Coach & Consultant \\
\hline $\begin{array}{c}\text { Level of } \\
\text { Responsibility }\end{array}$ & $\begin{array}{c}\text { Epistemological } \\
\text { Development, Self- } \\
\text { Directed Learning }^{c}\end{array}$ & \multicolumn{2}{|c|}{ Participation } & Contribution & Full Responsibility \\
\hline $\begin{array}{c}\text { Extent of } \\
\text { Teamwork }\end{array}$ & $\begin{array}{l}\text { Psychosocial } \\
\text { Development }^{\mathrm{d}}\end{array}$ & \multicolumn{2}{|c|}{ Class Project } & Individual Project & Small Group Project \\
\hline $\begin{array}{c}\text { Intensity/ } \\
\text { Duration of S-L } \\
\text { Project }\end{array}$ & $\begin{array}{l}\text { Experiential } \\
\text { Learning }^{\mathrm{e}}\end{array}$ & $\begin{array}{l}\text { One-time/ } \\
\text { Discrete }\end{array}$ & $\begin{array}{c}\text { Extended } \\
\text { Unit }\end{array}$ & Course-Basis & Long-term Commitment \\
\hline $\begin{array}{l}\text { Community } \\
\text { Contact }\end{array}$ & $\begin{array}{c}\text { Moral } \\
\text { Development }^{\mathrm{f}}\end{array}$ & $\begin{array}{l}\text { Hypothetical/ } \\
\text { Non-Direct }\end{array}$ & \multicolumn{2}{|c|}{ Indirect } & Direct \\
\hline
\end{tabular}

a'Belenky, Clinchy, Goldberger, \& Tarule, 1997; Kegan, 1998; King \& Kitchener, 1994; Magolda, Creamer, \& Meszaros, 2010; Magolda, 2000; Perry, 1998

${ }^{\mathrm{b}, \mathrm{c}}$ Ambrose, Bridges, DiPietro, Lovett, \& Norman, 2010; Brockett \& Hiemstra, 1991; Brookfield, 1985a, 1985b, 2013; Caffarella \& O'Donnell, 1987; Caffarella, 1993; Houle, 1988; Knowles, 1975; Merriam, Caffarella, \& Baumgartner, 2006; Mezirow, 1991; Tough, 1989

${ }^{\mathrm{d} B i l o d e a u}$ \& Renn, 2005; Cass, 1979; Chickering \& Reisser, 1993; Chickering, 1969; Erikson, 1993; Josselson, 1987; Schlossberg, Waters, \& Goodman, 1995; Wijeyesinghe \& Jackson, 2001

${ }^{\mathrm{e}} \mathrm{Kolb}, 1983$

${ }^{f}$ Gilligan, 1982, 2011; Kohlberg, 1969, 1984; Rest, Bebeau, \& Thomas, 1999; Rest, 1979 
Self-directed learning is also a helpful concept in determining faculty and student roles in servicelearning courses. Building upon the early work of Knowles (1975), Houle (1984, 1988), and Tough (1989), later theorists have described what self-directed learning looks like (Brockett \& Hiemstra, 1991; Brookfield, 1985a, 1985b; Caffarella, 1993; Caffarella \& O'Donnell, 1987), how the transformation in consciousness leads to self-directed learning (Mezirow, 1991), and how instructors might go about encouraging self-directed learning (Ambrose, Bridges, DiPietro, Lovett, \& Norman, 2010; Brookfield, 1988; Brookfield, 2013; Knowles, 1975). (For a thorough exploration of the evolution of this concept, see Merriam, Caffarella, \& Baumgartner, 2006, pp. 105-129). In 1975, Knowles defined self-directed learning as:

A process in which individuals take the initiative, with or without the help of others, in diagnosing their learning needs, formulating learning goals, identifying human and material resources for learning, choosing and implementing appropriate learning strategies, and evaluating learning outcomes. (p. 18)

Knowles' definition of the concept focuses largely on the actions and processes involved in selfdirected learning. Brookfield (1986) pointed out that we can also understand self-directed learning in terms of the characteristics of the learner. He described self-directed learners as "analytical, socially independent, inner-directed, individualistic, and possessed of a strong sense of self-identity" (p. 41). Yet, he also pointed out that self-directed learning often happens in collaboration and consultation with others and can entail learners placing themselves under the guidance of a teacher (Brookfield, 2013). Brookfield (2013) went on to say that self-directed learning is about being "empowered-to decide what is most important to you, how you want to go about learning it, and when you're done" (p. 92).

Knowles (1975) also elaborated on the difference between pedagogy, which he defined as "the art and science of teaching," mainly to children, and andragogy, which he defined as "the art and science of helping adults (or, even better, maturing beings) learn" (p. 19). Thus, the instructor's main goal is to help students to discover their own capacity to learn, rather than to deliver information. Brookfield (2013) argued that educators can help to develop self-directed learners by: building student self-confidence, helping students to become aware of their own learning preferences and habits, fostering informational literacy, and designing projects that help students learn how to manage their own learning world. Ambrose et al. (2010) presented a list of strategies that instructors might utilize to foster self-directed learning, common to all of the strategies was a sense of being transparent and fostering explicit reflection upon the learning process among students. They encouraged phased projects that gradually moved from instructor management to student management, while providing support during the transition. Both of these resources also encourage faculty to model through their own behavior the desired capacities of selfdirected learning.

\section{Application}

In the Three-Phased Model for Service-Learning Course Design, we use epistemological development and self-directed learning theory to articulate how faculty members' roles can evolve as students become more capable of complex metacognition and of guiding their own learning process. We suggest that faculty who are working with younger students or with students who have not been previously exposed to service-learning (or other more complex college instruction) need to take on the role of "authority" and gradually move toward reshaping that role within the classroom; in turn, their students are "participants" in a project. In other words, students are likely entering college with an assumption that the faculty member has all of the knowledge and will be imparting that knowledge to them. As such, it would be unfair for instructors to immediately expect students to take charge of their own learning and, by extension, their own service-learning project. Instead, faculty members can begin by assuming the role of lead facilitator of a service-learning project - that is, they would define the project and its outcomes, select the community partner, design and facilitate a timeline for the project, and help to ensure the 
quality of student products. In addition, they would focus on delivering the discipline-specific knowledge that would be helpful to students to complete their projects.

Building on the concept of scaffolding and the notion that transformational learning occurs in moments of discomfort (Mezirow, 1991), faculty might choose one aspect of the project in which they would step back and ask students to take on more leadership, thus providing a very clear scaffold - that is, the time for students to practice taking responsibility for their own learning. For example, rather than telling students exactly what a presentation on their project should include, faculty might instead ask students to collectively design an outline for the presentation as an in-class exercise. This subtle transition might be described as one in which a faculty member takes on the role of "guide" or "motivator." In this capacity, they are still designing most elements of the project (much like a tour guide designs and leads the tour), but they are gradually asking students to take on small pieces of ownership.

As faculty members observe students grasping these small elements of self-direction, they can begin to step back even more and invite students to make more of a contribution to their own learning process. In this "coaching" role, faculty might identify the community partners for a course and even the general idea of the project but would ask students to work with those partners to create a set of goals and expectations for the project as well as a timeline for its completion. While coaches might provide project management tools and frameworks for students, they would not fill in all the blanks. They would create check points at which students would need to provide updates on their projects, set up times to receive feedback from community partners, and set aside class time for helping students to work through challenges, but they would not be on-site with students working through every step of the project. By always being available for support and by creating clear guidelines that students can follow, faculty members at this stage are providing the scaffolding necessary for students to practice taking on selfdirected projects but are not leaving them completely free of guidance.

As students build capacity and become more responsible for what (and how) they need to learn to complete their projects, the faculty member becomes a consultant. Again, the faculty member is always there to provide advice to students and to support them in achieving success, but he or she is not managing the project or providing all of the tools to manage the project; nor is he or she telling the students which concepts and knowledge areas they should utilize as they go about accomplishing their projects. In our experience, moving toward this level of responsibility too soon can result in unsuccessful projects, disappointed community partners, and disillusioned students who blame their faculty member for lack of effective course design. Many senior capstone courses are designed at this level, but because we know that many adults do not reach the highest levels of epistemological development until after college (Belenky et al., 1997; King \& Kitchener, 1994; Magolda et al., 2010), a faculty member may never fully step back from managing the experience. For example, faculty might recruit a group of community partners to present possible projects to students in order to ensure some quality control for partners while also enabling students to have a sense of choice and self-direction in their projects. They might also allow students to approach them with alternative proposals the students have developed independently and approve these proposals if a student can demonstrate capacity for self-direction. This type of experience aligns well with - and should prepare students for-professional career expectations following graduation; in fact, it is often treated as a professional experience within the classroom.

While it is natural to align these faculty roles with classes that take place in the various years of college, it is also possible to think about gradually shifting the faculty role within one specific class. For example, one faculty member we worked with was frustrated that students in his sophomore-level communications class were not taking ownership in a service-learning course designed somewhere in the middle of the faculty role/student responsibility spectrum. Upon further conversations with this faculty member, we collectively identified that students were not demonstrating the capacity for self-directed learning that would be necessary at that level, largely because this was the first service-learning course to which they were exposed within their major. The faculty member decided to split the course into two phases. First, he designed and managed a full-class service-learning project with one community partner; he determined the project that would be accomplished, managed the timeline, provided the necessary tools, and helped students to reach a successful outcome (playing more of an authority role). Students 
used in-class time to work collectively on the project under his guidance. By engaging in transparent reflection on the process with his students and by being explicit about the decisions he was making and the role he was playing, he was able to help students to develop the capacity to then take on a small-group project themselves in the second half of the course; during this phase, he gradually moved into the coaching role.

\section{Consideration 3: Extent of Teamwork}

\section{Theoretical Background}

Cognitive development certainly impacts the third consideration-extent of teamwork - in that students who are more advanced, self-directed learners will likely be better able to succeed in team projects. However, we also posit that psychosocial development plays a significant role in the ability to complete projects in cooperation with community partners and with peers. Psychosocial development is a subset of psychological development, described by Evans, Forney, and Guideo-DiBrito (1998) as "the content of development, the important issues people face as their lives progress, such as how to define themselves, their relationships with others, and what to do with their lives" (p. 32). Identity development theories are included in this category. Erickson's (1963) psychosocial development theory was one of the earliest in this category and outlined eight stages shaped by issues or questions that individuals face throughout their lifespan. For example, the dilemma between intimacy and isolation is a major question in young adulthood, and the resolution between generativity and self-absorption becomes important in middle adulthood (Erikson, 1993). Chickering (1969; Chickering \& Reisser, 1993) expanded upon the concept of identity development when he proposed seven "vectors" to describe areas of development that young adults pursue, though not necessarily in a linear fashion or at the same rates as others in their age group. The vectors are: developing competence (intellectual, physical, and interpersonal); managing emotions; moving through autonomy toward interdependence; developing mature interpersonal relationships; establishing identity; developing purpose; and developing integrity. Later theories expanded upon Erickson's and Chickering's work to focus on the psychosocial development of women (Josselson, 1987), non-majority racial groups (see Wijeyesinghe \& Jackson, 2001, for an overview), and non-majority sexual identities (see Bilodeau \& Renn, 2005, for an overview). Schlossberg, Waters, and Goodman's transition model (1995) described the changes in perception that an individual experiences when progressing through stages or perspectives in psychosocial development. The most important theme among all of these theories of psychosocial development is that adults - from adolescence onward but especially in the young adult years - are often struggling with how to understand and express their own identity and, by extension, with how that identity influences the ways in which they relate to others. As young adults progress through stages of identity development, they are faced with difficult choices; the college experience often further heightens the necessity to struggle with and resolve these choices.

A summary of these theories would suggest that students likely enter college with a limited understanding of their own and others' identities and how those identities shape interpersonal relationships and skills. They may depend upon others (i.e., authority figures or societal norms) to define the meaning of their own identity or the identity of others. They may then begin to move through a phase of focusing on their own identity, sometimes to the extent of setting themselves in opposition to the identity of others, in a necessary journey toward self-understanding. They gradually develop the ability to seek and understand a sense of interdependence-a sense of how their own identity can be strong while also being understood in relation to others, and a sense of how to productively and respectfully work with those who either share or do not share their identity. As with cognitive development, the navigation and resolution between perspectives of self and others is important to this progression.

\section{Application}

We believe that the progression in psychosocial understanding is an underutilized tool in supporting and implementing group projects. Expecting students to easily, respectfully, and productively work with each 
other when they may be struggling so deeply with their own identity development may be an unfair expectation. Therefore, we propose that service-learning courses may benefit from a progressive coaching toward group projects and teamwork. Such collaboration would be highly structured and organized by the faculty member in early experience (thus relating to the "authority" role of faculty members), with clearly defined roles and expectations that students would not have to struggle to figure out themselves and with opportunities to practice the roles that students might choose to play later, much like a "rehearsal." In addition, we argue that students might benefit from a reversal in the order in which we often present group and individual challenges. We believe students would benefit from opportunities for individualized development (and, we hope, opportunities to better understand their own strengths and learning needs) early on, when they are also engaging in personal self-discovery from a developmental perspective. Such experiences (if well-advised by faculty members and or professional supervisors) might actually allow them to discover a sense of self-confidence and academic/professional proficiency that would better prepare them for group projects later in the college career.

\section{Consideration 4: Intensity and Duration of the Project}

\section{Theoretical Background}

Not all service-learning courses need to be highly intensive to be worthwhile. Faculty should consider the notion that lower-intensity and/or shorter projects are perfectly acceptable, and that the choice about the duration and intensity of the project should be informed by both their own needs and goals and the developmental readiness of their students. These choices can be influenced by the developmental theories presented thus far. For instance, students who are still progressing through their own identity development may appreciate a small, focused service-learning project that allows them to explore how their own identity relates to that of others in a comfortable and controlled environment. Likewise, students who are just beginning to understand how their own intellectual perspective can aid in their understanding of complex topics (i.e., epistemological development) may appreciate a low-risk project, short in duration but with many opportunities to process through reflection.

We also propose that the duration and intensity of a project can be informed by experiential learning theory. Kolb (1983) described a four-part experiential learning theory that has greatly informed servicelearning's pedagogical groundings. The model framed four components of the experiential learning cycle, including: concrete experience, reflective observation, abstract conceptualization, and active experimentation. Successful experiential learning should include all four of those components, though Kolb noted that the cycle might start at any point and move through the rest of the categories from there. Service-learning theory draws on this model, particularly in its emphasis on critical reflection as a key component of the learning process.

\section{Application}

We suggest that the experiential learning cycle can provide a useful framework when considering how to balance student experience (through service-learning) with the delivery and examination of course content. While all four elements should be included in any service-learning class, a faculty member might make choices about where to have students enter that cycle as well as how and where to spend class time. These choices are influenced by the extent of prior experience among students, in both the academic discipline and the community. For example, if students are just being introduced to an academic discipline and do not possess a great deal of expertise on how to understand and apply its theories, an instructor might choose to provide students with a high-quality but short (in duration) project that would expose them to real-life examples of what they will study in the discipline but not expect them to offer expertise right away. Thus, the instructor might begin with Kolb's notion of "concrete experience." He or she would then spend time helping students to intentionally process the experience (i.e., coached reflective observation) before moving into a guided abstract conceptualization (connecting that experience to concepts and theories inherent in the 
discipline). The instructor would be able to refer back to the shared experience of the students in a way that constantly informs course content and asks them to continually test theories against that initial experience (i.e., active experimentation). The balance here gives an instructor more time to walk students through abstract concepts, while still drawing on every stage of Kolb's model.

Conversely, an instructor who is designing an upper-level course could still use Kolb's model of experiential learning but may ask students to begin with some abstract ideas based on what they have learned in their discipline over the years and courses that came before. Students could then move into testing their ideas through active and highly engaged experimentation that is a more significant component of the course (public problem-solving, for example); they would have new concrete experiences upon which they would reflect and move toward revising their abstract ideas. Students at this level might be more confident in expressing their own ideas in relation to those of the discipline and therefore might also be more comfortable starting with abstract conceptualization. In either of these cases, the entire cycle is included in the course planning, but by placing emphasis on one component or another, the faculty member makes a decision about the duration and intensity of the project based on the prior knowledge and experience of the students.

\section{Consideration 5: Community Contact}

\section{Theoretical Background}

Unfortunately, it is not uncommon to hear disappointment in the stories of community partners whose student partners did not deliver agreed upon products or services. In our experience, community partners frequently note challenges in communication with students and with students' levels of professionalism. Again, this could be connected to students' level of cognitive and epistemological development - that is, their perception of where knowledge resides (e.g., in their professor or the classroom) could impact the level of respect given to community partners and/or the level to which they value the community experience. Likewise, students who are engrossed in a moment of psychosocial development in which they are struggling to come to terms with their own identity could find it difficult to dedicate the attention necessary for a successful professional-level relationship. And, put quite simply, students may lack the knowledge of what a professional relationship should look like (including expectations for appropriate dress, appropriate timeframes for communicating, etc.). One must consider all of these factors when seeking to understand students' ability (or inability) to work well with community partners. We propose that the moral and ethical development of traditional-aged college students may impact the quality of their relationships with community partners.

Research on the moral development of young adults is rooted largely in the work of Kohlberg (1969, 1984) and Gilligan (1982). Kohlberg called his model "justice reasoning" and focused on how an individual judges what is right, or how he or she determines whether to follow a given set of rules. Early stages of his model were marked by a sense of obligation to follow the rules in order to avoid punishment or, later, because it is in their personal self-interest to do so. Middle stages were marked by the desire to live in a socially acceptable way according to the people around you and the belief that all rules should apply equally to all people. Later stages were characterized by an individual's ability or inclination to evaluate rules and systems on the basis of some level of common or universal values, and with attention to the process through which rules and systems are developed and not just the final outcomes (Kohlberg, 1984, p. 44).

Gilligan $(1982,2011)$ presented a model that offered subtle variations to Kohlberg's model based on the experiences of women and the "ethic of care" as a substitute for justice. In her model, an individual moves from being self-centered and concerned with her own survival to: gaining a sense of responsibility; seeing goodness as self-sacrifice (putting others first); integrating her own needs with those of others; and finally coming to a decision on the "morality of nonviolence" (a principle of care for self and others) (Gilligan, 1982). She described being struck by "the power of the opposition between selfishness and selflessness to shape women's moral judgments and guide the choices they made" (2011, p. 21). 
Rest and colleagues (Rest, 1979; Rest, Bebau, \& Thoma, 1999) modified Kohlberg's model into what they called a "neo-Kohlbergian" approach, including schemas (rather than stages) of moral development, based on their experiences in administering the "Defining Issues Test," or DIT. They argued that making moral judgments was only one component of moral development (Rest et al., 1999, p. 57). In describing the differences between their two schema ("maintaining norms" and "postconventional"), Rest et al. (1999) focused on how an individual attempts to achieve consensus. Though the approach to their model was intentionally different from Kohlberg's staged theory, they do note that similar underlying ideas exist; a shift from moral authority derived from external sources to a sense of ideals as the root of moral perspectives is an example of the commonality among the theories.

These theories share the notion that moral development often includes a shift from "doing what you are told" according to the rules of others, to focusing on the limited perspectives of either self-benefit or the desire to please others, to the development of a sense of moral values that can reconcile self-interest with respect and care for others. Again, we see a parallel to cognitive and psychosocial development in this eventual ability to reconcile perspectives that evolves later as a component of moral development.

\section{Application}

In relation to community partnerships, we argue that students often enter college at earlier levels of moral development. They may be well-versed at following the rules of school or at "doing school" in a way that either promotes their self-interest (translated to good grades) or pleases authority figures (or both). They are likely not at a stage where they are making judgments about what is good or right based on a welldeveloped sense of moral values; in translation, they are likely to see the purpose of education as getting good grades and moving toward graduation, perhaps getting a job. They are less likely to be thinking about the moral and ethical purposes of education or the inherent value of examining and forming intellectual ideas. A service-learning experience will require students to consider the perspectives of others (i.e., their peers, their instructors, and their community partners) and make judgments about how to reconcile those perspectives with their own self-interest or desire to please-something they have likely not had to do often in an academic setting. It will also invite them to find purpose in their education in a new way.

We believe that instructors must be protective of both their students and their community partners when they enter into a service-learning project or course. Recognizing that students are struggling with the balance between self-interest and the needs of others can help faculty to coach students through their work with community partners. They can help students to explicitly name the different expectations that are being placed on them, and the dissonance that this may cause in their understanding of or judgment about "why" they should do something (e.g., turn in an assignment, work hard on a project, show up to a meeting, meet a deadline, etc.). We suggest that faculty begin with projects that are hypothetical (using real-life examples but not necessarily working with those organizations - a precursor to service-learning) or non-direct (working with a real organization but within the confines of the classroom or in limited event-based community exposure, with the instructor serving as the project lead and primary communicator). After initial and well-facilitated practice, partnerships can move toward indirect relationships; in this model, students are working with nonprofit organizations, but they are not working directly with the served population and might instead be working on background projects (e.g., they might work with a staff person at a daycare center but not with the children themselves). The purpose is to gradually expose students to the most vulnerable community members and to protect those community members from the consequences of a mismatch between students' self-interest and responsibility. Eventually, we hope that students will have the maturity and perspective-taking ability to work in direct relationship with community members and, hopefully, to have a sense of accountability to those partners as well as a sense of the value of the experience for themselves. This balanced perspective-taking, a hallmark of later phases of moral development, will lead to more positive, equal, and productive partnerships.

As an example of the ways in which this model could apply to and impact community partnerships, consider a project in which groups of students write research papers proposing solutions for a challenge 
being faced by a community partner. We believe that this project design can present challenges and, in fact, could cause harm to community partners if assigned without careful consideration of students' developmental perspectives. The danger here is two-pronged, encompassing both cognitive and moral perspectives. From a cognitive perspective, students may be in a place where the answers to these solutions seem simple; their suggested solutions may therefore lack awareness of complexity and, in turn, end up being less than useful to their partners. From a moral and ethical development perspective, students who are motivated by self-interest or by the desire to please their professor may rush to write papers that provide simple solutions much in the same manner they would write an academic paper. The ability to discover and integrate the perspectives and needs of their partner might therefore be left out of the process. Again, the partner would not benefit from such a project. We do not intend to suggest that this type of project is impossible, but we do suggest a few alterations or additions to the assignment. First, we suggest that students be encouraged to work with community partners rather than for them, thus addressing the problematic stance of "consultant" and instead focusing on collaboration. This is only possible if the community partner is invested enough in a solution and has the time and capacity to work hand-in-hand with students in finding it. If possible, however, the collaboration inherent in this project could be extremely powerful for students. In addition (as a complement to the shift toward collaboration), we would also encourage faculty utilizing this approach to transparently and intentionally talk with students about the limitation of their knowledge, the need for collaboration, and the potential damage that could be caused by jumping to conclusions or over-simplifying issues. Students will need a balance of challenge and support in this situation, so that they do not feel they are being set up for failure by their faculty member. For all of these reasons, we strongly believe that this kind of project should be reserved for highly experienced service-learners. If working with less experienced service-learners (even seniors who have not worked in partnership with community before), we suggest taking this project down a notch in terms of its judgmental nature. Instead, perhaps invite students to work with community partners on a solution pre-identified by the partner, thus exposing them to the solution-seeking process but not placing them in charge of it.

\section{Putting it All Together: The Three-Phased Model for Service-Learning Course Design}

\section{Basic Overview}

In order to simplify these five considerations and provide a useful model for faculty, we have created a condensed instructor handout that summarizes the Three-Phased Model for Service-Learning Course Design (see Appendix). The final handout blends the various developmental considerations and omits detailed developmental terminology in favor of practical, pedagogical terminology (Table 2). The overarching progression moves through three phases: exposure, capacity building, and responsibility. The goals of phase one (exposure) are introducing students to service-learning, building initial skills, introducing the process of academic reflection, and beginning to build cultural and interpersonal competencies. The goals of phase two (capacity building) focus on increasing expectations for students to take responsibility for outcomes, practicing professional skills, and becoming more adept reflective thinkers. The goals of phase three (responsibility) include moving students toward high-level ownership of projects, mastering skills, and demonstrating high-level critically reflective thinking and expression. In each phase, we suggest pedagogical designs that answer the question, "What should service-learning look like at this phase?" The model is intentionally designed with three flexible phases, in part to avoid the suggestion that service-learning evolves evenly across the four years of a typical academic experience. Rather, we suggest that there are moments at which phases overlap with each other, and that there is time built in for transition between phases depending upon the needs of the students, the faculty member, and the department or institution. 
56 | International Journal of Research on Service-Learning and Community Engagement

Table 2. Three-Phased Model for Service-Learning Course Design, Basic Course Considerations

\begin{tabular}{llll}
\hline Course Consideration & Phase 1: Exposure & $\begin{array}{l}\text { Phase 2: Capacity } \\
\text { Building }\end{array}$ & $\begin{array}{l}\text { Phase 3: } \\
\text { Responsibility }\end{array}$ \\
\hline Instructor Role & Primary Manager & Facilitator & Coach or Consultant \\
\hline $\begin{array}{l}\text { Level of } \\
\text { Responsibility }\end{array}$ & Participation & Contribution & Full Responsibility \\
\hline $\begin{array}{l}\text { Extent of } \\
\text { Teamwork }\end{array}$ & Class Project & Individual Project/Role & Small Group Project \\
\hline $\begin{array}{l}\text { Intensity/Duration of } \\
\text { S-L Project }\end{array}$ & One-Time/Discrete & Course-basis & $\begin{array}{l}\text { Long-Term } \\
\text { Commitment }\end{array}$ \\
\hline Community Contact & $\begin{array}{l}\text { Hypothetical/ } \\
\text { Non-Direct }\end{array}$ & Indirect & Direct \\
\hline
\end{tabular}

\section{Suggested Uses: Individual and Departmental}

We believe that the three-phased model can be useful on two levels: for an individual faculty member who is creating a single course or for a department/unit that is considering integration of service-learning throughout the curriculum. It can also be used by either faculty themselves or by a service-learning staff member who is consulting with them. We have shared examples of such conversations from our own experience above. In addition, this model was originally inspired by our involvement in an "Engaged Department" Initiative (Battistoni, Gelmon, Wergin, \& Zlotkowski, 2003). Although curriculum development is only one component of such an initiative (it should also include cultural considerations, policies, and processes), it is a core component of defining how engagement can lie at the heart of a department's values and practices.

\section{The Model's Influence on Reflective Practice}

We also suggest that faculty and departments consider student development and its influence on the reflection activities and assignments that are used within service-learning. Just as projects can be designed to align with student readiness and capacity, reflection assignments can be designed to gradually remove the support of faculty guidance. For example, a first-year course might use questionnaires and faculty-led dialogue to process an experience; a capacity-building course might ask students to come up with their own guiding questions or invite them to use metaphor and visual imagery to process experiences; and a senior-level course could invite a more open-ended reflection format in which students could structure their own reflective process. Students who are asked to reflect in this open-ended fashion in their first service-learning experience may feel confused or paralyzed if not provided with more direction but will overcome that paralysis when gradually introduced to reflective practice.

\section{Accounting for Developmental Variability among Students}

It is not our intention to create a "one-size-fits-all" model that will easily apply to any and all students. Instructors will find that students in their classes are in different developmental positions for a variety of reasons - classes will include non-traditional students with varying life experiences, students who have varying levels of service-learning experience, and students who have either missed out on or not been coached through developmental milestones. Rather than being intimidated by these variations or frozen in their tracks when they emerge, there are ways in which instructors might prepare for them (both mentally and in their course planning). For example, if an instructor finds that he or she has mature students in a class or students who clearly have an advanced epistemological or moral perspective, he or 
she might find room for those students to take on roles as team leaders, primary contacts with community partners, or discussion leaders in class. If there are students in the class who are struggling more than others, instructors might plan ahead for drop-in support time with teaching assistants or instructors; additionally, instructors will need to take an active role in encouraging students to take advantage of these times. Instructors might also strategically pair more advanced students with less advanced students, asking them to pair up for in-class discussions in which they know that one might challenge the other. Likewise, lining up three or four projects for a class and intentionally ensuring that one or two of them are more or less advanced than the others provides options for faculty to guide students toward appropriate projects. Taking some intentional time to get to know students at the beginning of the semester (or getting information from prior instructors) could help instructors to place students in the appropriate projects and to provide the appropriate level of challenge and support for each group. The developmental variation among students can also be alleviated, to some extent, by pursuing a departmental approach to engagement that results in student progression through a common series of experiences as they move through their major (or other set of common courses). In short, appropriate use of this model requires periodic, formal, and informal assessment that will enable instructors to adapt and adjust their approach in response to their own instincts and/or student or community feedback.

\section{Conclusion}

The most important goal for us in creating this model was to improve the experiences of students, faculty, and community partners who participate in service-learning courses. We believe that this model could be helpful in other contexts - for designing undergraduate research programs, for example, or other experiential learning curricula. However, we believe that there is something unique about the campuscommunity relationship in service-learning that makes consideration of developmental perspectives especially important. There are consequences when projects fail, impacting our students, our community partners, and our town-gown relationships; such failure can lead to discouragement and a lack of desire on the part of stakeholders to continue to utilize this pedagogical approach or to continue partnering with each other. And yet, we know that this pedagogy can have positive impacts on our students and community partners when implemented effectively. As such, we hope that our three-phased model contributes to effective practices in the service-learning field by not only articulating what works but by articulating what works at certain stages and by giving faculty members a flexible menu of options to achieve increased success. In addition, we hope that the model helps faculty members to troubleshoot challenges they are facing by giving them insight into the natural progression of student development, thus eliminating the feeling that they or their students are somehow failing at service-learning. We believe that this scaffolded approach can improve the frequency and level of student and faculty success, and thereby build increased confidence in the transformative potential of service-learning 


\section{Appendix}

\section{Three-Phased Model Faculty Handout (Page 1)}

\section{Service-Learning in the Curriculum: A Three-Phased Developmental Model}

Service-learning courses and partnerships can be more successful for all stakeholders if they are designed to align with and build student capacity over time.

By understanding student development and considering the skills and knowledge levels of the students with whom you will be working, you can design a project that:

$>$ Aligns expectations with competencies;

$>$ Offers the appropriate balance of challenge and support;

$>$ Builds student skills to progressively prepare them for the next level;

$>$ and Results in more positive and reciprocal relationships with partners.

Consider designing your service-learning course or program to align with the following three (flexible) phases. Keep in mind that the phases are meant to exist on a spectrum and may not be so clearly unique from each other as the visual representation in this model suggests. Instructors should adjust as they see fit.

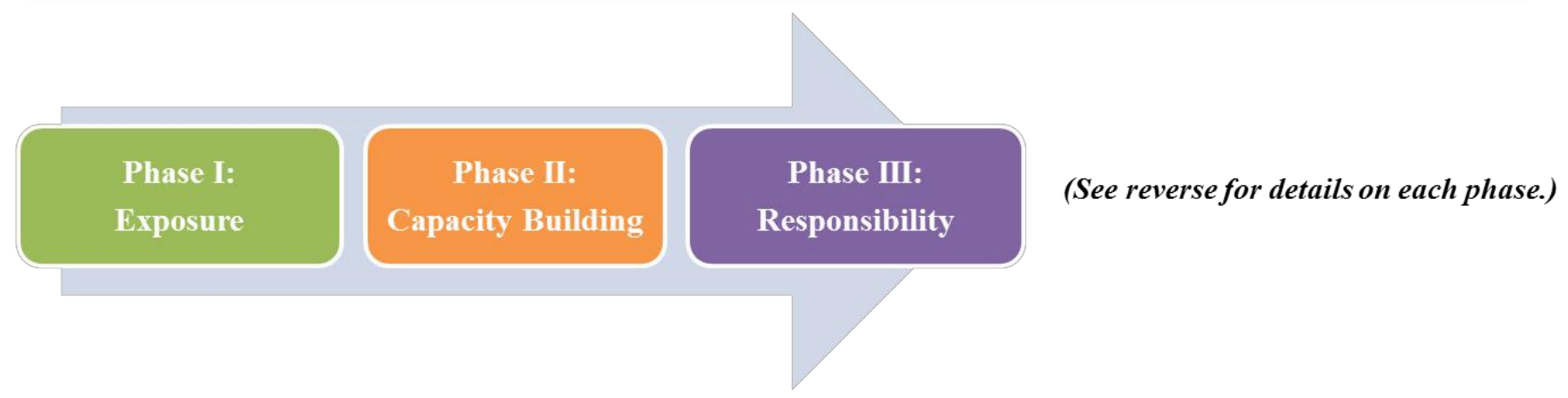

While this model is helpful in designing service-learning courses that stand alone, it is also meant to spur conversation within a given academic unit or progressive curriculum. The more we build our students'capacity, the higher they can achieve in the long run. 
Three -Phased Model Faculty Handout (Page 2)

\begin{tabular}{|c|c|c|c|}
\hline $\begin{array}{l}\text { From Theory to Practice: } \\
\text { What do courses look like } \\
\text { when they align with the } \\
\text { three-phased model? }\end{array}$ & $\begin{array}{l}\text { Phase I: } \\
\text { Exposure }\end{array}$ & $\begin{array}{l}\text { Phase II: } \\
\text { Capacity Building }\end{array}$ & $\begin{array}{l}\text { Phase II: } \\
\text { Responsibility }\end{array}$ \\
\hline Goals of this Phase & $\begin{array}{l}\text { Introducing service-learning and } \\
\text { course content/concepts; } \\
\text { - Initial skill development; } \\
\text { - Introducing academic reflection; } \\
\text { - Building cultural and interpersonal } \\
\text { competencies. }\end{array}$ & $\begin{array}{l}\text { - Increasing expectations, student } \\
\text { responsibility for outcomes; } \\
\text { - Practicing personal/professional } \\
\text { skills introduced previously; } \\
\text { - Progressing to higher-levels of } \\
\text { critically reflective thinking. }\end{array}$ & $\begin{array}{l}\text { High-level student accountability } \\
\text { for outcomes; } \\
\text { - Skill mastery, with professional } \\
\text { development and application; } \\
\text { - Mastering higher levels of critically } \\
\text { reflective thinking and expression. }\end{array}$ \\
\hline Instructor Role & $\begin{array}{l}\text { Primary Manager - define project, } \\
\text { facilitate student interaction with } \\
\text { partner, outline clear processes and } \\
\text { expectations, provide close guidance. }\end{array}$ & $\begin{array}{l}\text { Facilitator-provide structure but } \\
\text { require student project management; } \\
\text { select partners and establish } \\
\text { outcomes, but invite student input. }\end{array}$ & $\begin{array}{l}\text { Coach or Consultant - suggest } \\
\text { strategies and structure, but empower } \\
\text { students to implement and innovate. } \\
\text { Monitor progress. }\end{array}$ \\
\hline $\begin{array}{c}\text { Level of } \\
\text { Responsibility }\end{array}$ & $\begin{array}{l}\text { Participation - design projects that } \\
\text { invite students to join under your } \\
\text { leadership, emphasize skill-building } \\
\text { they will utilize later. }\end{array}$ & $\begin{array}{l}\text { Contribution - gradually step back } \\
\text { as students take more responsibility; } \\
\text { invite student contributions to project } \\
\text { design, process, and outcomes. }\end{array}$ & $\begin{array}{l}\text { Full Responsibility - support students } \\
\text { as they take charge of identifying and } \\
\text { managing some or all project } \\
\text { components. }\end{array}$ \\
\hline $\begin{array}{l}\text { Extent of } \\
\text { Teamwork }\end{array}$ & $\begin{array}{l}\text { Class Project-guide the entire class } \\
\text { in a collaborative project ensuring } \\
\text { each student finds a valuable role. }\end{array}$ & $\begin{array}{l}\text { Individual Project/Role - help } \\
\text { students foster skills and capacities by } \\
\text { taking on individual projects and/or } \\
\text { components of projects. }\end{array}$ & $\begin{array}{l}\text { Small Group Project-ask students to } \\
\text { create or join team-based projects, and } \\
\text { to use previously developed skills to } \\
\text { work effectively with others. }\end{array}$ \\
\hline $\begin{array}{l}\text { Intensity/Duration of } \\
\text { S-L Project }\end{array}$ & $\begin{array}{l}\text { One-Time/Discrete - integrate a } \\
\text { clearly defined and time-limited S-L } \\
\text { project. Apply course content to this } \\
\text { "case" throughout the semester. }\end{array}$ & $\begin{array}{l}\text { Course-basis - shift to a balance } \\
\text { between course content and S-L with } \\
\text { a project that extends across a longer } \\
\text { time-period, requires more attention. }\end{array}$ & $\begin{array}{l}\text { Long-Term Commitment - project is } \\
\text { central focus of the course (such as a } \\
\text { capstone), requiring use of content } \\
\text { knowledge from prior courses. }\end{array}$ \\
\hline Community Contact & $\begin{array}{l}\text { Hypothetical/Non-Direct - maintain } \\
\text { your control over student exposure to } \\
\text { partners; projects may take place } \\
\text { within the classroom. }\end{array}$ & $\begin{array}{l}\text { Indirect - get students "onsite," but } \\
\text { carefully manage direct contact with } \\
\text { community consider "background" } \\
\text { support. }\end{array}$ & $\begin{array}{l}\text { Direct -students work on site with } \\
\text { populations served or general public. } \\
\text { They manage contact with partners. }\end{array}$ \\
\hline
\end{tabular}


60 | International Journal of Research on Service-Learning and Community Engagement

\section{Correspondence}

Correspondence concerning this article should be addressed to: Carrie Williams Howe, Executive Director, Vermont Campus Compact, Colchester, VT 05439; cwilliamshow@smcvt.edu

\section{References}

Ambrose, S. A., Bridges, M., DiPietro, M., Lovett, M., \& Norman, M. (2010). How learning works: Seven research-based principles for smart teaching. San Francisco, CA: Jossey-Bass.

Battistoni, R., Gelmon, S., Wergin, J., \& Zlotkowski, E. (2003). Engaged department toolkit. Boston, MA: Campus Compact.

Belenky, M. F., Clinchy, B. M., Goldberger, N. R., \& Tarule, J. M. (1997). Women's ways of knowing: The development of self, voice, and mind (10 anniversary ed.). New York, NY: Basic Books.

Berle, D. (2006). Incremental integration: A successful service-learning strategy. International Journal of Teaching and Learning in Higher Education, 18(1), 43-48.

Bilodeau, B. L., \& Renn, K. A. (2005). Analysis of LGBT identity development models and implications for practice. New Directions for Student Services, 111, 25-39.

Bradley, L. R. (2003). Using developmental and learning theory in the design and evaluation of K-16 service-learning programs. In S. Billig \& A. Waterman (Eds.), Studying service-learning: Innovations in education research methodology (pp. 47-72). Mahwah, NJ: Lawrence Erlbaum Associates.

Brockett, R. G., \& Hiemstra, R. (1991). Self-direction in adult learning: Perspectives on theory, research, and practice. New York, NY: Routledge.

Brookfield, S. (1985a). Self-directed learning: A critical review of research. New Directions for Adult and Continuing Education, 1985(25), 5-16.

Brookfield, S. (1985b). Self-directed learning: From theory to practice. San Francisco, CA: JosseyBass.

Brookfield, S. (1986). Understanding and facilitating adult learning: A comprehensive analysis of principles and effective practices. San Francisco, CA: Jossey-Bass.

Brookfield, S. (2013). Powerful techniques for teaching adults. San Francisco, CA: Jossey-Bass.

Brookfield, S. D. (1988). Understanding and facilitating adult learning. School Library Media Quarterly, 16(2), 99-105.

Bruner, J. S. (1956). A study of thinking. New York, NY: Wiley.

Butin, D. (2003). Of what use is it? Multiple conceptualizations of service learning within education. The Teachers College Record, 105(9), 1674-1692.

Caffarella, R. S. (1993). Self-directed learning. New Directions for Adult and Continuing Education, 1993(57), 25-35.

Caffarella, R. S., \& O’Donnell, J. M. (1987). Self-directed adult learning: A critical paradigm revisited. Adult Education Quarterly, 37(4), 199-211.

Campus Compact. (2013). Creating a culture of assessment: 2012 Campus Compact annual member survey. Boston, MA: Campus Compact.

Cass, V. C. (1979). Homosexuality identity formation: A theoretical model. Journal of Homosexuality, 4(3), 219-235.

Chickering, A. W. (1969). Education and identity. San Francisco, CA: Jossey-Bass.

Chickering, A. W., \& Reisser, L. (1993). Education and identity. San Francisco, CA: Jossey-Bass.

Enos, S. L., \& Troppe, M. L. (1996). Service-learning in the curriculum. In B. Jacoby \& Associates (Eds.), Service-learning in higher education (pp.156-181). San Francisco, CA: Jossey-Bass.

Erikson, E. H. (1993). Childhood and society. New York, NY: W. W. Norton \& Company. 
Evans, N. J., Forney, D. S. \& Guido-DiBrito, F. (1998). Student development in college: Theory, research, and practice. San Francisco, CA: Jossey-Bass.

Eyler, J., \& Giles, D. E. (1999). Where's the learning in service-learning. San Franscisco, CA: Jossey-Bass.

Eyler, J., Giles, D., Stenson, C., \& Gray, C. (2001). At a glance: What we know about the effects of service-learning on college students, faculty, institutions, and communities, 1993-2000 (3 ${ }^{\text {rd }} \mathrm{ed}$.). Washington, DC: Corporation for National and Community Service.

Gilligan, C. (1982). In a different voice: Psychological theory and women's development. Cambridge, MA: Harvard University Press.

Gilligan, C. (2011). Joining the resistance. Malden, MA: Polity Press.

Gordon, R. (2000). Problem based service learning: A field guide for making a difference in higher education. Concord, NH: Campus Compact for New Hampshire.

Heffernan, K. (2001). Fundamentals of service-learning course construction. Boston, MA: Campus Compact.

Houle, C. O. (1984). Patterns of learning. New perspectives on life-span education. New York, NY: Wiley

Houle, C. O. (1988). The inquiring mind: A study of the adult who continues to learn. Norman, OK: Oklahoma Research Center for Continuing Professional and Higher Education.

Howard, J. (1993). Community service learning in the curriculum. In J. Howard (Ed.), Praxis I: A faculty casebook on community service learning, (pp. 3-12). Ann Arbor, MI: OCSL Press.

Howard, J. (2001). Service-learning course design workbook. Ann Arbor, MI: OCSL Press.

Jameson, J., Clayton, P., \& Bringle, R. (2008). Investigating student learning within and across linked service-learning courses. In M. Bowdon, S. Billig, \& B. Holland (Eds.), Advances in service-learning research: Scholarship for sustaining service-learning and civic engagement ( $\mathrm{pp}$. 3-27). Greenwich, CT: Information Age Publishing.

Josselson, R. (1987). Finding herself: Pathways to identity development in women. San Fransciso, CA: Jossey-Bass.

Kegan, R. (1998). In over our heads: The mental demands of modern life. Cambridge, MA: Harvard University Press.

King, P. M., \& Kitchener, K. S. (1994). Developing reflective judgment. San Francisco, CA: JosseyBass.

Knowles, M. S. (1975). Self-directed learning. New York, NY: Association Press.

Kohlberg, L. (1969). Stage and sequence: The cognitive-developmental approach to socialization. New York, NY: Rand McNally.

Kohlberg, L. (1984). Essays on moral development: The nature and validity of moral stages (Vol. 2). San Francisco, CA: Harper \& Row.

Kolb, D. A. (1983). Experiential learning: Experience as the source of learning and development. Englewood Cliffs, NJ: Prentice Hall.

Kuh, G. (2008). High-impact educational practices: What they are, who has access to them, and why they matter. Washington, DC: Association of American Colleges and Universities.

Magolda, M. B. B. (2000). Creating contexts for learning and self-authorship: Constructivedevelopmental pedagogy. Nashville, TN: Vanderbilt University Press.

Magolda, M. B. B., Creamer, E. G., \& Meszaros, P. S. (Eds.). (2010). Development and assessment of self-authorship: Exploring the concept across cultures. Sterling, VA: Stylus Publishing.

McEwan, M. (1996). Enhancing student learning and development through service-learning. In B. Jacoby \& Associates (Eds.). Service-learning in higher education: Concepts and practices (pp. 53-91). San Francisco, CA: Jossey-Bass.

Merriam, S. B., Caffarella, R. S., \& Baumgartner, L. M. (2006). Learning in adulthood: A comprehensive guide ( $3^{\text {rd }}$ ed.). San Francisco, CA: Jossey-Bass.

Mezirow, J. (1991). Transformative dimensions of adult learning. San Francisco, CA: Jossey-Bass. 
62 International Journal of Research on Service-Learning and Community Engagement

Mintz, S. D., \& Hesser, G. W. (1996). Principles of good practice in service-learning. In B. Jacoby \& Associates (Eds.), Service-learning in higher education: Concepts and practices, (pp. 26-52). San Francisco, CA: Jossey-Bass.

Morton, K. (1996). Issues related to integrating service-learning into the curriculum. In B. Jacoby \& Associates (Eds.), Service-learning in higher education: Concepts and practices, (pp. 276-296). San Francisco, CA: Jossey-Bass.

Perry, W. G. (1998). Forms of ethical and intellectual development in the college years: A scheme. San Francisco, CA: Jossey-Bass.

Piaget, J. (1952). The origins of intelligence in children ( $2^{\text {nd }}$ ed., M. Cook, Trans.). New York, NY: International Universities Press. (Original work published 1936)

Piaget, J. (1972). Intellectual evolution from adolescence to adulthood. Human Development, 15(1), $1-12$.

Rest, J. R. (1979). Development in judging moral issues. Minnesota, MN: University of Minnesota Press.

Rest, J. R., Bebeau, M. J., \& Thoma, S. J. (1999). Postconventional moral thinking: A neoKohlbergian approach. Mahwah, NJ: Lawrence Erlbaum Associates.

Sanford, N. (Ed.). (1962). The American college: A psychological and social interpretation of the higher learning. New York, NY: John Wiley \& Sons.

Schlossberg, J., Waters, R., \& Goodman, P. (1995). Counseling adults in transition: Linking theory with practice. New York, NY: Harper \& Row.

Seifer, S., \& Connors, K. (2007). Faculty toolkit for service-learning in higher education. Scotts Valley, CA: National Service-Learning Clearinghouse.

Steinke, P., Fitch, P., Johnson, C., \& Waldstein, F. (2002). An interdisciplinary study of servicelearning predictors and outcomes among college students. In S. Billig \& A. Furco (Eds.), Service-learning through a multidisciplinary lens (pp. 73-102). Greenwich, CT: Information Age Publishers.

Terry, A. W., \& Bohnenberger, J. E. (2004). Blueprint for incorporating service learning: A basic, developmental, K-12 service learning typology. Journal of Experiential Education, 27(1), 15-31.

Tough, A. (1989). Self-directed learning: Concepts and practice. In C.J. Titmus (Ed.), Lifelong education for adults: An international handbook (pp. 256-260). Oxford: Pergamon.

Vygotsky, L. S. (1962). Thought and language. (E. Hanfmann \& G. Vakar, Trans.). Cambridge, MA: Massachusetts Institute of Technology Press.

Vygotsky, L. S. (1978). Mind in society: The development of higher psychological processes (M. Cole, V. John-Steiner, S. Scribner, E. Souberman, Eds.) Cambridge, MA: Harvard University Press.

Warter, E. H., \& Grossman, J. M. (2002). An application of developmental contextualism to servicelearning. In A. Furco \& S. Billig (Eds.). Service-learning: The essence of the pedagogy (pp. 83102). Greenwich, CT: Information Age Publishers.

Wijeyesinghe, C., \& Jackson, B. W. (Eds.). (2001). New perspectives on racial identity development: A theoretical and practical anthology. New York, NY: New York University Press. 